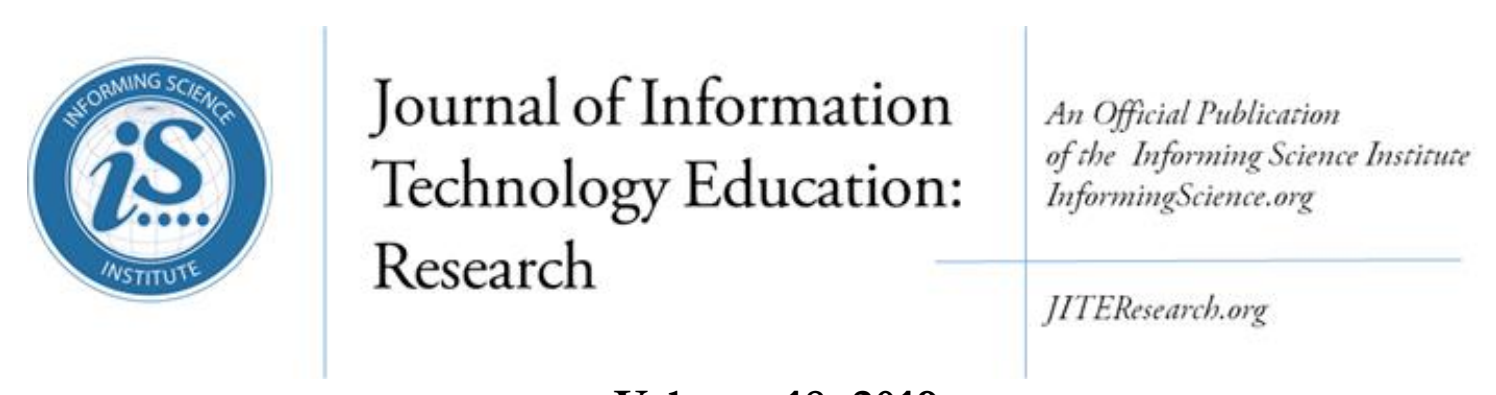

Volume 18, 2019

\title{
DOES SIZE MATTER? INSTRUCTORS’ AND STUDENTS’ Perceptions of Students' Use of TeCHNOLOGY IN THE ClassROOM
}

$\begin{array}{lll}\text { Christine Zaza* } & \begin{array}{l}\text { University of Waterloo, } \\ \text { Waterloo, ON, Canada }\end{array} & \text { zaza@,uwaterloo.ca } \\ \text { Elena Neiterman } & \begin{array}{l}\text { University of Waterloo, } \\ \text { Waterloo, ON, Canada }\end{array} & \text { eneiterman@ } 0 \text { uwaterloo.ca } \\ * \text { Corresponding author } & & \end{array}$

\begin{abstract}
Aim/Purpose The aim of this study was to explore whether students' self-initiated personal technology use differ by class size as well as to explore students and instructors' perspectives on whether students' technology use in class is a problem.

Background Because class size influences several aspects of student engagement, it is plausible that class size would affect students' technology behaviours, but, to our knowledge, no study has directly examined class size as a factor in students' onand off-task technology use. There is also a paucity of research on how the use of off-task technology affects instructors.
\end{abstract}

Methodology We surveyed all undergraduate students and faculty in one Faculty at a Canadian university in Fall 2016. A total of 478 students and 36 instructors completed the survey. The survey contained questions about students' and instructors' behaviours and attitudes towards the use of technology in class. Quantitative data were analyzed in SPSS and Excel and qualitative excerpts from short-answer questions on the survey were analyzed in NVIVO 8.

Contribution This paper demonstrates that students' on- and off-task technology use in class is influenced by class-size. It also informs us on the impact students' technology use has on instructors in the academic classroom.

Findings Student-initiated technology use increased significantly as class size increased. Students and instructors expressed little concern about the impact of classrelated technology use on learning and views did not differ significantly between these two groups. Although both students and instructors believed offtask technology use hinders learning, their views differed significantly, with

Accepting Editor Elsje C Scott | Received: February 19, 2019| Revised: May 30, July 21,2019 | Accepted: July 31, 2019.

Cite as: Zaza, C., \& Neiterman, E. (2019). Does size matter? Instructors' and students' perceptions of students' use of technology in the classroom. Journal of Information Technology Education: Research, 18, 379-393. https://doi.org/10.28945/4411

(CC BY-NC 4.0) This article is licensed to you under a Creative Commons Attribution-NonCommercial 4.0 International License. When you copy and redistribute this paper in full or in part, you need to provide proper attribution to it to ensure that others can later locate this work (and to ensure that others do not accuse you of plagiarism). You may (and we encourage you to) adapt, remix, transform, and build upon the material for any non-commercial purposes. This license does not permit you to use this material for commercial purposes. 
more instructors than students feeling strongly that students' use of technology in class is a problem.

Recommendations We need to develop guidelines on how to address off-task technology use in for Practitioners class.

Recommendation for Researchers More research is needed to explore how the use of technology in class affects instructors.

Impact on Society Higher education industry needs to consider how to manage the use of off-task technology in class.

Future Research We need to explore further how to mitigate the factors contributing to the offtask technology use in academic classroom.

Keywords media in education, post-secondary education, pedagogical issues, improving classroom teaching, laptop multitasking

\section{INTRODUCTION}

Since the early 2000s, students' use of laptops, phones, and tablets in the post-secondary classrooms has become widespread (Aguilar-Roca, Williams, \& O’Dowd, 2012; Alkahtani et al., 2016; Awwad, Ayesh, \& Awwad, 2013; Gaudreau, Miranda, \& Gareau, 2014). For students, the benefits of using technology in class include improved accessibility and increased opportunities for interactive, engaged, and instant-feedback in learning. Students use technology to take notes, access course material, and/or to engage in instructor-led online quizzes, polls, and educational games as a part of their courses (Awwad et al., 2013; Taneja, Fiore, \& Fischer, 2015). But the spread of laptops and other devices in the classroom has also opened the door to the use of technology for off-task purposes such as browsing the Internet or social media sites, shopping, or even watching videos while in class (Awwad et al., 2013; Fried, 2008; Ravizza, Hambrick, \& Fenn, 2014). For two decades, the focus of research has been on students' off-task use of technology in class and its effects on learning. The aim of this study was to explore whether students' self-initiated personal technology use differ by class size as well as to explore students and instructors' perspectives on whether students' technology use in class is a problem.

After a brief review relevant literature we outline our study methods and approach to analysis. Our findings are presented in the Results section, followed by a Discussion section which includes a graphic summary of the findings (see Figure 3). Our Conclusion highlights the contribution of our research and points to future directions that build on this study.

\section{LITERATURE REVIEW}

Several studies have shown that students use technology in class for off-task purposes. Off-task technology use in class negatively affects learning for the technology user as well as for those around them (Grinols \& Rajesh 2014; Junco \& Cotton, 2012; Lee, Lin, \& Robertson, 2012; Sana, Weston, \& Cepeda, 2013; Wood et al., 2012). Despite being aware of these negative effects on learning, students continue to use technology for off-task purposes in class (Langan et al., 2016; Santos, Bocheco, \& Habak, 2018).

In recent years, attention has turned to examining the factors that influence students' use of technology in class for off-task purposes (Gupta \& Irwin, 2016; Langan et al., 2016). Recent research shows that technology use is higher when students' level of interest and engagement in the lecture is low (Gupta \& Irwin, 2016; Langan et al., 2016) and when students perceive a low level of instructor's competence and caring (Ledbetter \& Finn, 2016). Learning in a class of 25 students is very different from learning in a class of 450 students. The same is true for teaching: the physical distance from students in a large lecture hall can make it more challenging for instructors to connect with and en- 
gage their students. Because class size influences several aspects of student engagement (Burruss, Billings, Brownrigg, Skiba, \& Connors, 2009), it is plausible that class size would affect students' technology behaviours. To our knowledge, however, no study has directly examined class size as a factor in students' on- and off-task technology use. Therefore, in this exploratory study, our goal is to examine if students' self-initiated use of personal technological devices differs by class size.

It is widely recognized that instructors perceive students' off-task use of technology in class as a problem (Junco \& Cotton, 2012; Langan et al., 2016; Sana et al., 2013; Santos et al., 2018; Wood et al., 2012). However, little is known about whether or not students also consider this to be a problem as few current studies have explored both students' and instructors' views (Baker, Lusk, \& Neuhauser, 2012; Santos \& Bocheco, 2016; Santos et al., 2018). It is important to understand and consider both students' and instructors' perspectives on defining this problem because both groups are affected by measures directed toward addressing these behaviours. Common strategies for addressing this problem include incorporating technology as educational tools (Awwad et al., 2013), establishing technology zones for laptop-users (Aguilar-Roca et al., 2012), educating students on the impact of off-task technology use on academic performance (Rosen, Whaling, Carrier, Cheever, \& Rokkum, 2013), and banning technology altogether (Baker et al., 2012; Beland \& Murphy, 2016; Mboga, Mboga, \& Nyaanga, 2016). This last measure is concerning, because in many jurisdictions, including Canada, banning technology in class violates human rights of students with disabilities who use technology as a necessary accommodation (Carter, Greenberg, \& Walker, 2017). In addition, strict methods of policing adult students' use of technology are not always effective (Santos et al., 2018) or recommended (Gupta \& Irwin, 2016). Nevertheless, evidence-based, widespread guidelines for technology use in class are yet to be developed.

The goal of this project is to explore students' and instructors' perspectives on technology use in class and the role class size plays in technology-related distractions. Specifically, we examine two questions:

(1) Does students' technology use pose the same level of distraction in all class sizes? and

(2) Do students and instructors consider students' technology use in class a problem?

\section{MATERIALS AND METHODS}

In Fall, 2016 upon receiving ethics approval from the University's ethics review board, we invited all undergraduate students and faculty members in the Faculty of Applied Health Sciences at a large research-focused university in Ontario, Canada, to participate in an online survey examining students' technology use in their academic classrooms. We created a 15-item survey for students and a nineitem survey for instructors, with seven items common to both surveys. The students' survey included questions about student-initiated on-task and off-task technology use in small ( $<30$ students), medium (31-69 students), and large ( $\geq 70$ students) classes. We also asked students and instructors for their perceptions about the degree to which technology use in class hinders learning. Specifically, we asked students to report how they were affected by the sound of other students typing, and seeing course-related and non-course-related material on other students' screens in large, medium, and small classes.

The survey distinguished between instructor-initiated technology use (i.e., instructors' use of technologies such as Twitter, iClickers, class polling tools, PollEverywhere, Top Hat, Kahoot, etc., for educational purposes, while teaching) and student-initiated use of technology (i.e., students' use of their cell phones, laptops, or tablets for a variety of purposes). Student-initiated technology use was further defined in the survey as class-related (i.e., taking notes, looking something up) and non-class related (i.e., checking email, texting, browsing internet sites). Survey questions asked about studentinitiated technology use in small ( $<30$ students), medium (31-69 students), and large ( $\geq 70$ students) face-to-face classes. Most questions used 5-point Likert scales response options and two questions were open-ended. The question In your opinion, should instructors try to minimize technology-related distrac- 
tions during class? included the response options Yes, No, and Undecided, with text fields for respondents to elaborate on their response. In an open-ended question for additional comments, participants were not asked to distinguish between small, medium, and large class sizes. We used the same wording on both surveys, wherever possible.

The survey was administered online through Survey Monkey and the survey invitation and consent form was sent to all the participants via the email listservs for faculty members and students. The survey was available for three weeks and after the first two-weeks, one electronic reminder was sent to the potential participants. All students who participated in the survey were invited to enter into a draw to win one of four $\$ 25$ gift cards to a popular chain of coffee shops.

Quantitative data were analyzed in Excel 2016 and SPSS Version 25 (means, frequencies, T-tests, ChiSquare). Open-ended responses were coded inductively for emerging themes using Braun and Clarke (2006) step-by-step process. Both sets of data were analyzed separately and then consolidated during the final stage of analysis. In what follows, we summarize the major findings from our analysis. In a separate paper we report an in-depth analysis of the open-ended survey responses along with data from focus groups that were conducted after the survey (Neiterman \& Zaza, 2019).

\section{RESULTS}

A total of 478 students and 36 instructors completed the survey, representing approximately $21 \%$ of undergraduate students and $47 \%$ of instructors in the Faculty. At the time of the survey, $51 \%$ ( $\mathrm{n}=$ 18) of instructors were teaching an in-person undergraduate course on campus. Seventy-nine percent $(n=348)$ of students identified with the female gender, $21 \%(n=91)$ identified as male, and $0.5 \%$ $(n=2)$ identified themselves as "other" gender. The distribution of females and males in our sample is representative of the gender distribution in the Faculty. There was good representation from all four years of study in the student sample: $29 \%$ of students were in $1^{\text {st }}$ year, $18 \%$ were in $2^{\text {nd }}$ year, $30 \%$ were in $3^{\text {rd }}$ year, and $23 \%$ were in $4^{\text {th }}$ year. Seventy-two students and 9 instructors provided open-ended comments in the survey.

\section{DoEs STUdentS'Use OF PERSONAL TECHNOLOGICAL DEVICES DIFFER BY CLASS SIZE?}

Students self-reported using technology in class for both class-related and off-task purposes. Overall, $65 \%$ of students reported using technology for class-related purposes and $20 \%$ used it for off-task purposes. Breaking this down by class size revealed that both types of technology use were more common in large ( $\geq 70$ students) classes than in medium (31-69 students) or small ( $<30$ students) classes. In each of the three class sizes, the mean ratings of students' class-related technology use were significantly higher than their off-task use (large class: $\mathrm{t}=13.36, \mathrm{df}=380, \mathrm{p}<0.001$; medium class: $\mathrm{t}=14.93, \mathrm{df}=317, \mathrm{p}<0.001$; small class: $\mathrm{t}=15.93, \mathrm{df}=327, \mathrm{p}<.001)$. Table 1 shows frequencies, means and standard deviations, and, for ease of interpretation; Figure 1 shows the means.

Table 1. Students' Self-reported Technology Use in Class

\begin{tabular}{|l|l|l|l|l|l|l|l|}
\hline & \multicolumn{1}{|c|}{$\begin{array}{c}\mathbf{1} \\
\text { Never }\end{array}$} & $\begin{array}{c}\mathbf{2} \\
\text { Very } \\
\text { Rarely }\end{array}$ & $\begin{array}{c}\mathbf{3} \\
\text { Sometimes }\end{array}$ & $\begin{array}{c}\mathbf{4} \\
\text { Often }\end{array}$ & $\begin{array}{c}\mathbf{5} \\
\text { Always }\end{array}$ & $\begin{array}{l}\text { Total } \\
\text { Sean }\end{array}$ & $\begin{array}{c}\text { Mean } \\
(\mathbf{s d})\end{array}$ \\
\hline \multicolumn{2}{|c|}{ Students' Self-reported Class-Related Technology Use in Class } \\
\hline Small & 41 & 57 & 60 & 80 & 100 & 338 & 3.42 \\
& $12.1 \%$ & $16.9 \%$ & $18.1 \%$ & $24.2 \%$ & $29.6 \%$ & & $(1.38)$ \\
\hline Medium & 28 & 29 & 48 & 96 & 129 & 330 & 3.82 \\
& $8.5 \%$ & $8.9 \%$ & $14.5 \%$ & $29.1 \%$ & $39 \%$ & & $(1.28)$ \\
\hline Large & 21 & 39 & 52 & 120 & 162 & 394 & 3.92 \\
& $5.3 \%$ & $9.9 \%$ & $13.2 \%$ & $30.5 \%$ & $41.1 \%$ & & $(1.19)$ \\
\hline
\end{tabular}




\begin{tabular}{|l|l|l|l|l|l|l|l|}
\hline & $\begin{array}{c}1 \\
\text { Never }\end{array}$ & $\begin{array}{c}\mathbf{2} \\
\text { Very } \\
\text { Rarely }\end{array}$ & $\begin{array}{c}\mathbf{3} \\
\text { Sometimes }\end{array}$ & $\begin{array}{c}\mathbf{4} \\
\text { Often }\end{array}$ & $\begin{array}{c}\mathbf{5} \\
\text { Always }\end{array}$ & Total & $\begin{array}{c}\text { Mean } \\
(\mathbf{s d})\end{array}$ \\
\hline Students' Self-reported Off-task Technology Use in Class \\
\hline Small & 111 & 127 & 58 & 28 & 9 & 333 & 2.09 \\
& $33.3 \%$ & $38.1 \%$ & $17.4 \%$ & $8.4 \%$ & $2.7 \%$ & & $(1.04)$ \\
\hline Medium & 37 & 124 & 103 & 52 & 9 & 325 & 2.61 \\
& $11.4 \%$ & $38.2 \%$ & $31.7 \%$ & $16 \%$ & $2.8 \%$ & & $(0.98)$ \\
\hline Large & 20 & 117 & 137 & 87 & 23 & 384 & 2.94 \\
& $5.2 \%$ & $30.5 \%$ & $35.7 \%$ & $22.7 \%$ & $6 \%$ & & $(0.99)$ \\
\hline
\end{tabular}

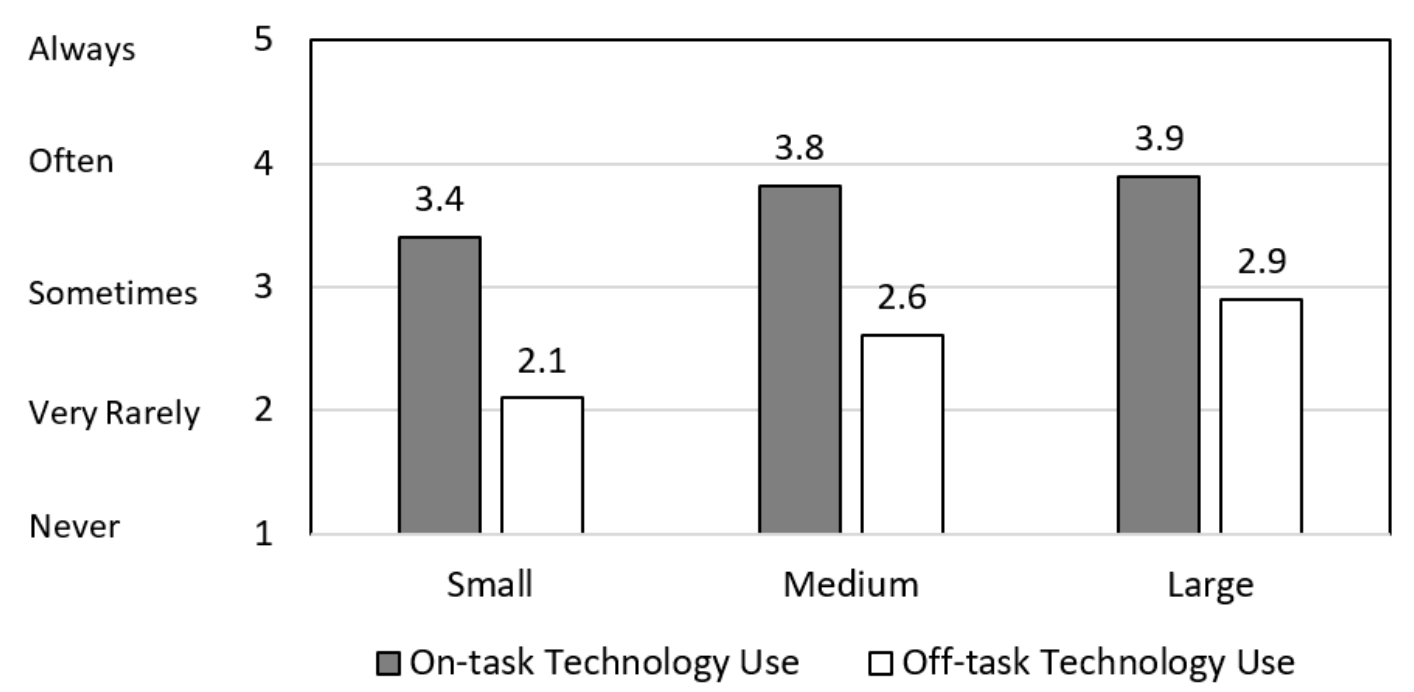

Figure 1. Students' Self-Reported Use of Personal Technological Devices in Small, Medium, and Large Class Sizes

\section{DO STUDENTS AND INSTRUCTORS CONSIDER STUDENTS'TECHNOLOGY USE IN CLASS AS A PROBLEM?}

We asked instructors and students to indicate their level of agreement with five statements about students' self-initiated personal technology use in class. As Table 2 shows, both instructors and students expressed little concern about class-related technology use and the mean ratings from these two groups were not significantly different $(\mathrm{p}>0.05)$. However, both groups expressed concerns about off-task technology use with instructors' ratings being significantly higher than students' ratings. Students and instructors also differed significantly in their overall perception of technology use in class, with instructors feeling more strongly that it is a problem (see Table 2). 
Table 2. Perceptions of Students' Technology Use in Class

\begin{tabular}{|c|c|c|c|c|c|c|c|c|}
\hline & & \multicolumn{5}{|c|}{ Strongly disagree -1 to Strongly agree -5} & \multirow[t]{2}{*}{ Total } & \multirow{2}{*}{$\begin{array}{c}\text { Mean } \\
(\mathrm{SD})\end{array}$} \\
\hline Statement & Group* & 1 & 2 & 3 & 4 & 5 & & \\
\hline \multirow{2}{*}{$\begin{array}{l}\text { When students use lap- } \\
\text { tops, tablets, or phones in } \\
\text { class for class-related pur- } \\
\text { poses it hinders their abil- } \\
\text { ity to do well in the } \\
\text { course. }\end{array}$} & $\mathrm{S}$ & $\begin{array}{l}177 \\
40.3 \%\end{array}$ & $\begin{array}{l}131 \\
29.8 \%\end{array}$ & $\begin{array}{l}78 \\
17.8 \%\end{array}$ & $\begin{array}{l}46 \\
10.5 \%\end{array}$ & $\begin{array}{l}7 \\
1.6 \%\end{array}$ & 439 & $\begin{array}{l}2.03 \\
(1.07)\end{array}$ \\
\hline & $\mathrm{I}$ & $\begin{array}{l}8 \\
26.7 \%\end{array}$ & $\begin{array}{l}12 \\
40 \%\end{array}$ & $\begin{array}{l}5 \\
16.7 \%\end{array}$ & $\begin{array}{l}5 \\
16.7 \%\end{array}$ & $\begin{array}{l}0 \\
0 \%\end{array}$ & 30 & $\begin{array}{l}2.23 \\
(1.04)\end{array}$ \\
\hline \multirow{2}{*}{$\begin{array}{l}\text { When students use lap- } \\
\text { tops, tablets, or phones in } \\
\text { class for class-related pur- } \\
\text { poses it hinders other } \\
\text { students' ability to do well } \\
\text { in the course. }\end{array}$} & S & $\begin{array}{l}151 \\
34.5 \%\end{array}$ & $\begin{array}{l}131 \\
29.9 \%\end{array}$ & $\begin{array}{l}90 \\
20.5 \%\end{array}$ & $\begin{array}{l}55 \\
12.6 \%\end{array}$ & $\begin{array}{l}11 \\
2.5 \%\end{array}$ & 438 & $\begin{array}{l}2.19 \\
(1.12)\end{array}$ \\
\hline & I & $\begin{array}{l}3 \\
10 \%\end{array}$ & $\begin{array}{l}12 \\
40 \%\end{array}$ & $\begin{array}{l}11 \\
36.7 \%\end{array}$ & $\begin{array}{l}4 \\
13.3 \%\end{array}$ & $\begin{array}{l}0 \\
0 \%\end{array}$ & 30 & $\begin{array}{l}2.53 \\
(0.86)\end{array}$ \\
\hline \multirow{2}{*}{$\begin{array}{l}\text { When students use lap- } \\
\text { tops, tablets, or phones in } \\
\text { class for purposes unre- } \\
\text { lated to class it hinders } \\
\text { their ability to do well in } \\
\text { the course.** }\end{array}$} & S & $\begin{array}{l}9 \\
2.1 \%\end{array}$ & $\begin{array}{l}21 \\
4.8 \%\end{array}$ & $\begin{array}{l}45 \\
10.3 \%\end{array}$ & $\begin{array}{l}196 \\
44.7 \%\end{array}$ & $\begin{array}{l}167 \\
38.1 \%\end{array}$ & 438 & $\begin{array}{l}4.12^{* *} \\
(0.92)\end{array}$ \\
\hline & I & $\begin{array}{l}1 \\
3.3 \%\end{array}$ & $\begin{array}{l}0 \\
0 \%\end{array}$ & $\begin{array}{l}1 \\
3.3 \%\end{array}$ & $\begin{array}{l}10 \\
33.3 \%\end{array}$ & $\begin{array}{l}18 \\
60 \%\end{array}$ & 30 & $\begin{array}{l}4.47 * * \\
(0.86)\end{array}$ \\
\hline \multirow{2}{*}{$\begin{array}{l}\text { When students use lap- } \\
\text { tops, tablets, or phones in } \\
\text { class for purposes unre- } \\
\text { lated to class it hinders } \\
\text { other students' ability to } \\
\text { do well in the course. }\end{array}$} & S & $\begin{array}{l}23 \\
5.3 \%\end{array}$ & $\begin{array}{l}51 \\
11.7 \%\end{array}$ & $\begin{array}{l}67 \\
15.3 \%\end{array}$ & $\begin{array}{l}185 \\
42.3\end{array}$ & $\begin{array}{l}111 \\
25.4 \%\end{array}$ & 437 & $\begin{array}{l}\text { 3.71** } \\
(1.13)\end{array}$ \\
\hline & $\mathrm{I}$ & $\begin{array}{l}1 \\
3.3 \%\end{array}$ & $\begin{array}{l}0 \\
0 \%\end{array}$ & $\begin{array}{l}3 \\
10 \%\end{array}$ & $\begin{array}{l}17 \\
56.7 \%\end{array}$ & $\begin{array}{l}9 \\
30 \%\end{array}$ & 30 & $\begin{array}{l}4.10^{* *} \\
(0.85)\end{array}$ \\
\hline \multirow{2}{*}{$\begin{array}{l}\text { In general, students' use } \\
\text { of laptops, tablets, or } \\
\text { phones in class is a prob- } \\
\text { lem. }\end{array}$} & $\mathrm{S}$ & $\begin{array}{l}127 \\
28.9 \% \\
\end{array}$ & $\begin{array}{l}119 \\
27.1 \%\end{array}$ & $\begin{array}{l}120 \\
27.3 \%\end{array}$ & $\begin{array}{l}63 \\
14.4 \%\end{array}$ & $\begin{array}{l}10 \\
2.3 \%\end{array}$ & 439 & $\begin{array}{l}2.34 \int \\
(1.11)\end{array}$ \\
\hline & $\mathrm{I}$ & $\begin{array}{l}1 \\
3.3 \%\end{array}$ & $\begin{array}{l}2 \\
6.7 \%\end{array}$ & $\begin{array}{l}16 \\
53.3 \%\end{array}$ & $\begin{array}{l}7 \\
23.3 \%\end{array}$ & $\begin{array}{l}4 \\
13.3 \%\end{array}$ & 30 & $\begin{array}{l}3.37 \mathrm{~J} \\
(0.93)\end{array}$ \\
\hline
\end{tabular}

$* \mathrm{~S}=$ students, $\mathrm{I}=$ instructors; $* * \mathrm{p}<.05 ; \rrbracket \mathrm{p}<.01$

We also asked instructors and students if they felt that instructors should minimize technologyrelated distractions in class. Instructors' and students' responses to this question differed significantly: $60 \%$ of instructors $(n=18)$ and only $26 \%(n=116)$ of students answered the question affirmatively $($ Chi Square $=17.85, \mathrm{df}=2, \mathrm{p}<0.01)$. As shown in Figure 2, approximately one-third of instructors $(\mathrm{n}=9)$ and students $(\mathrm{n}=147)$ were undecided. 


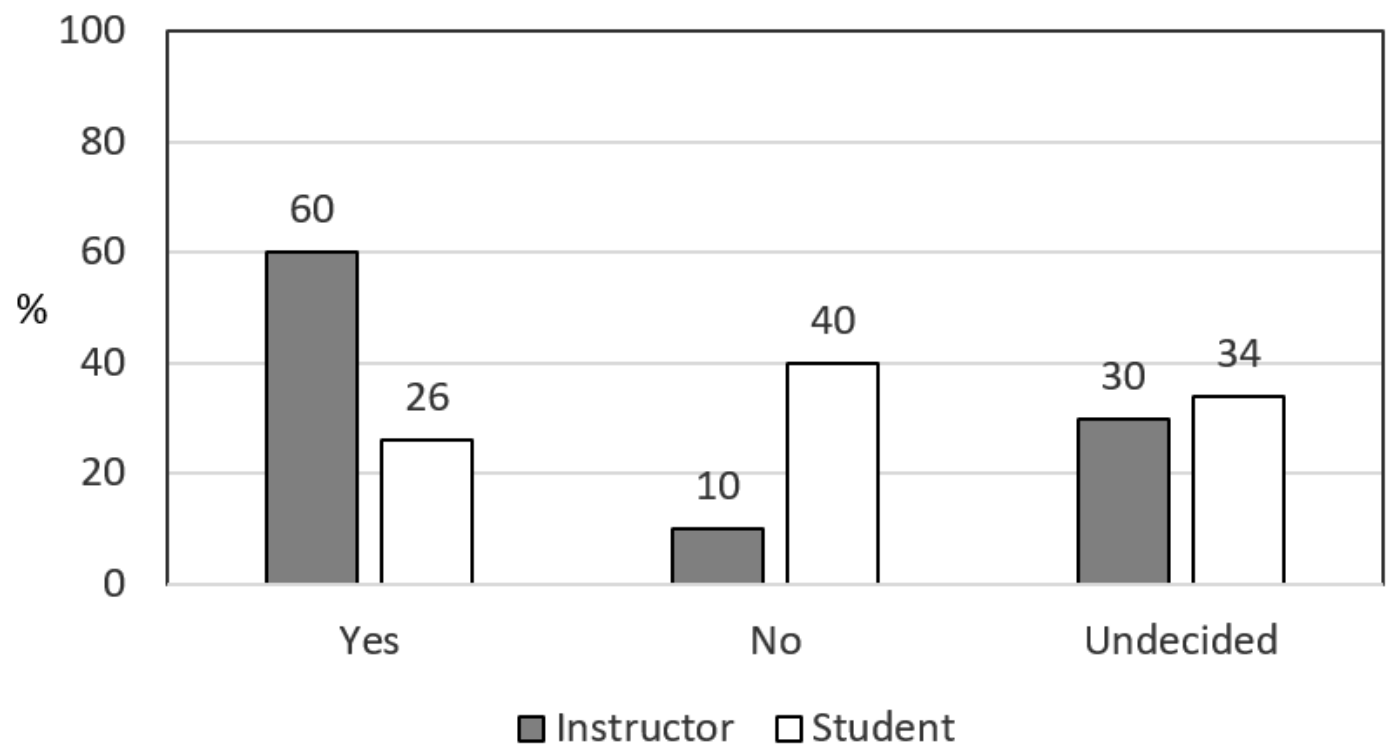

Figure 2. Should instructors minimize technology-related distractions in class?

\section{DoEs STUDENTS'TECHNOLOGY USE POSE THE SAME LEVEL OF DISTRACTION IN ALL CLASS SIZES?}

We asked students to consider how distracting they found the sound of typing (e.g. for note taking), seeing course-related material (e.g. lecture slides) on others' screens, and seeing unrelated material (e.g., Internet sites) on others' screens. Overall, seeing class-related material on others' screens was either "somewhat" or "very" distracting to approximately $9 \%$ of students whereas seeing material that is unrelated to class was either "somewhat" or "very" distracting to $49 \%$ of students. The sound of students typing was "somewhat" or "very" distracting to approximately $22 \%$ of students. For all three of these potential distractions, the percentage of students who found these being "somewhat" or "very" distracting was higher in large class sizes compared to smaller classes. Table 3 presents these data broken down by class size.

Table 3. Students' Perceptions of Distractions Caused by Technology Use in Class

\begin{tabular}{|c|c|c|c|c|c|c|c|}
\hline & $\begin{array}{c}1 \\
\text { This does } \\
\text { not distract } \\
\text { me at all }\end{array}$ & $\begin{array}{c}2 \\
\text { This does } \\
\text { not distract } \\
\text { me very } \\
\text { much }\end{array}$ & $\begin{array}{c}3 \\
\text { Neutral }\end{array}$ & $\begin{array}{c}4 \\
\text { This is } \\
\text { somewhat } \\
\text { distracting } \\
\text { to me }\end{array}$ & $\begin{array}{c}5 \\
\text { This is very } \\
\text { distracting to } \\
\text { me }\end{array}$ & Total & $\begin{array}{c}\text { Mean } \\
\text { (sd) }\end{array}$ \\
\hline \multicolumn{8}{|c|}{ Seeing course-related material (e.g., lecture slides) } \\
\hline Small & $\begin{array}{l}185 \\
56 \%\end{array}$ & $\begin{array}{l}70 \\
21.2 \%\end{array}$ & $\begin{array}{l}48 \\
14.5 \%\end{array}$ & $\begin{array}{l}22 \\
6.7 \%\end{array}$ & $\begin{array}{l}5 \\
1.5 \%\end{array}$ & 330 & $\begin{array}{l}1.76 \\
(1.03)\end{array}$ \\
\hline Medium & $\begin{array}{l}167 \\
51.5 \% \\
\end{array}$ & $\begin{array}{l}74 \\
22.8 \%\end{array}$ & $\begin{array}{l}56 \\
17.3 \% \\
\end{array}$ & $\begin{array}{l}25 \\
7.7 \% \\
\end{array}$ & $\begin{array}{l}2 \\
0.6 \% \\
\end{array}$ & 324 & $\begin{array}{l}1.83 \\
(1.01)\end{array}$ \\
\hline Large & $\begin{array}{l}201 \\
52.6 \% \\
\end{array}$ & $\begin{array}{l}88 \\
23 \% \\
\end{array}$ & $\begin{array}{l}55 \\
14.4 \% \\
\end{array}$ & $\begin{array}{l}32 \\
8.4 \% \\
\end{array}$ & $\begin{array}{l}6 \\
1.6 \%\end{array}$ & 382 & $\begin{array}{l}1.83 \\
(1.06)\end{array}$ \\
\hline \multicolumn{8}{|c|}{ Seeing material that is unrelated to the course (e.g., email, internet sites, videos, etc.) } \\
\hline Small & $\begin{array}{l}75 \\
22.9 \%\end{array}$ & $\begin{array}{l}59 \\
18 \%\end{array}$ & $\begin{array}{l}51 \\
15.6 \%\end{array}$ & $\begin{array}{l}86 \\
26.3 \%\end{array}$ & $\begin{array}{l}56 \\
17.1 \%\end{array}$ & 327 & $\begin{array}{l}2.97 \\
(1.43)\end{array}$ \\
\hline Medium & $\begin{array}{l}61 \\
18.8 \%\end{array}$ & $\begin{array}{l}55 \\
16.9 \%\end{array}$ & $\begin{array}{l}50 \\
15.4 \%\end{array}$ & $\begin{array}{l}113 \\
34.8 \%\end{array}$ & $\begin{array}{l}46 \\
14.2 \%\end{array}$ & 325 & $\begin{array}{l}3.09 \\
(1.35)\end{array}$ \\
\hline Large & $\begin{array}{l}51 \\
13.2 \% \\
\end{array}$ & $\begin{array}{l}84 \\
21.8 \% \\
\end{array}$ & $\begin{array}{l}46 \\
11.9 \% \\
\end{array}$ & $\begin{array}{l}143 \\
37.1 \% \\
\end{array}$ & $\begin{array}{l}61 \\
15.8 \% \\
\end{array}$ & 385 & $\begin{array}{l}3.21 \\
(1.31) \\
\end{array}$ \\
\hline
\end{tabular}




\begin{tabular}{|c|c|c|c|c|c|c|c|}
\hline & $\begin{array}{c}1 \\
\text { This does } \\
\text { not distract } \\
\text { me at all }\end{array}$ & $\begin{array}{c}2 \\
\text { This does } \\
\text { not distract } \\
\text { me very } \\
\text { much }\end{array}$ & $\begin{array}{c}3 \\
\text { Neutral }\end{array}$ & $\begin{array}{c}4 \\
\text { This is } \\
\text { somewhat } \\
\text { distracting } \\
\text { to me }\end{array}$ & $\begin{array}{c}5 \\
\text { This is very } \\
\text { distracting to } \\
\text { me }\end{array}$ & Total & $\begin{array}{c}\text { Mean } \\
\text { (sd) }\end{array}$ \\
\hline \multicolumn{8}{|c|}{ The sound of other students typing on their laptops or tablets } \\
\hline Small & $\begin{array}{l}134 \\
39.9 \%\end{array}$ & $\begin{array}{l}81 \\
24.1 \%\end{array}$ & $\begin{array}{l}48 \\
14.3 \%\end{array}$ & $\begin{array}{l}52 \\
15.2 \%\end{array}$ & $\begin{array}{l}21 \\
6.3 \%\end{array}$ & 336 & $\begin{array}{l}2.24 \\
(1.29)\end{array}$ \\
\hline Medium & $\begin{array}{l}124 \\
37.5 \%\end{array}$ & $\begin{array}{l}72 \\
21.8 \%\end{array}$ & $\begin{array}{l}72 \\
21.8 \%\end{array}$ & $\begin{array}{l}45 \\
13.6 \%\end{array}$ & $\begin{array}{l}18 \\
5.4 \%\end{array}$ & 331 & $\begin{array}{l}2.28 \\
(1.25)\end{array}$ \\
\hline Large & $\begin{array}{l}142 \\
36.3 \%\end{array}$ & $\begin{array}{l}102 \\
26.1 \%\end{array}$ & $\begin{array}{l}53 \\
13.6 \%\end{array}$ & $\begin{array}{l}71 \\
18.2 \%\end{array}$ & $\begin{array}{l}23 \\
5.9 \%\end{array}$ & 391 & $\begin{array}{l}2.31 \\
(1.29)\end{array}$ \\
\hline
\end{tabular}

\section{Students' and instructors' perceptions}

In their open-ended responses, students commented that it is "very distracting when students watch movies or scroll through social media during class (Student\# 235569)" or "when they are surfing the web or doing work that is not class related..." (Student\# 971330). As one student commented, "it is] extremely distracting when students are using technology for unrelated coursework, especially when they sit toward the front of the room (Student\# 48438)". For some students, the computer screen itself created a distraction and therefore was more bothersome than the use of the phone, as noted in the following quote:

I find other students' use of technology for unrelated purposes most distracting on a laptop as compared to a phone, since the screen is much larger and brighter, and more visible since it is propped up (Student\# 676985).

For others, it was the sound, rather than the visual, that created a distraction:

I am mainly affected by the noises coming from students' use of technology during class rather than what is on their screens. The sounds coming from their Facebook chats, text message notifications, and their phones going off bother me the most (Student\# 46168)

Overall, the written comments seemed to indicate that it is the position of the screen as well as the screen content that may create a distraction for students. The sound of typing, on the other hand, has been perceived as both, stimulating and impeding learning. Only two students commented specifically on the negative effect of hearing the sound of typing, suggesting that it can be "distracting to hear the clicking of keys in the lecture hall" and that it is "difficult to hear the professor without the additional noise of keys clicking". On the other hand, some students commented on the helpful aspect of hearing the sound of typing, noting that it can be used as "a cue to take notes, even if I find nothing salient to record" (Student\# 246688). As another student explained

It is more helpful than detrimental. The sound of typing may even alert some students that, since everyone is typing, that means the instructor said something important or there is an addition they bave to make to the slides the professor put up that is inconsistent with the slides the professor posted on the student copy (Student\# 777812).

Students' comments focused on the benefits of technology use for note-taking. As one student commented:

Technology has been the main reason behind my success in my classes. I find it much easier to follow a Power Point on my own laptop, and it enables me to make my own notes on my Power Points which I prefer over written notes (Student\# 699204).

For many students, technology has become a necessary tool for learning and, even when they acknowledge its potential negative uses, they still saw it as beneficial for learning, overall. One of the students noted: 
Personally, I find it beneficial to bring my laptop to class. I think it helps keep me organized when taking notes. It is very annoying to watch some students browse the Internet or chat on Facebook or other messenger apps. So I think those people need to somehow be told to sit at the back of the classroom. It makes no difference to me if students are on their laptops, looking at the course's slides, or taking notes. But it is distracting when I see them looking at non-school related content. Like celebrity sites, shopping sites, etc. (Student\# 7012442)

Whether or not students are bothered by others' technology use in class, many pointed out that adapting to technology in the classroom is necessary in the world where the technology use is firmly integrated into workplace and everyday life:

We live in a technology-driven society, and the same technology-related distractions will be present in the real world when we begin working as they are now during class. Students who can adapt to the distractions and use technology to their advantage will succeed. Self-motivation and self-control are important skills to learn (Student\# 6736757).

Echoing this student's position that self-control should be exercised in the use of technology, many students emphasized the importance of autonomy and personal responsibility in their use of technology as well as in managing distractions of others' technology use in class. One of the students pointed out:

We are adults not children. If other people's technology distracts you, sit at the front. If your technology is distracting you, put it away or don't bring it. We are responsible for our own learning (Res \# 6797408).

The sense of personal responsibility was tied not only to the adulthood, but also to the context of economic exchange in which higher education is offered. One of the students commented:

Students are paying for their own education. Students are 17+ and not children. They should be able to use their time however they feel fit. If it is distracting, students can sit in the front of the class (Res \# 006153).

In Canada, students pay for their education, and in the past few years, the cost of higher education has risen substantially. As this student suggested, students may see themselves as consumers who are entitled to make decisions about how they use the time that they have in the classroom, given that they purchased it with their own money.

Instructors indicated an array of positive and negative views on the use of technology. Some instructors welcomed technology in the classroom and saw it as a new medium of learning, suggesting that "we should use it more to engage ... [students] in active learning e.g., searching for info, interpreting, comparing, creating online assignments (Instructor\# 5053301834)." Conversely, others had a more negative view: As one instructor commented, "I understand the issues related to inclusive teaching practices, but I am often tempted to BAN laptops and cell phones from my class." (Instructor\# 5053485942). Approximately two-thirds of instructors $(n=21,67.7 \%)$ reported that they were bothered by students' use of cellphones whereas as one-third of instructors were bothered by students' use of laptops or tablets in the class $(n=10$, $32 \%$ ). Not all instructors felt that students' use of technology is a problem: one instructor commented that students "might be used to it more than we think." (Instructor\# 5066817768) and another noted that this is "more of an issue in undergraduate classes" (Instructor\# 5076150199) than in graduate classes.

\section{DISCUSSION}

This pilot study explored whether there was an association between class size and students' on- and off-task self-initiated use of personal technological devices in the undergraduate classroom. We also focused on students' and instructors' perceptions about the use of technology in class. Our study showed that student-initiated class-related and off-task technology use is present in classrooms of all sizes -- across all class sizes, $64 \%$ of students reported class-related technology use and $20 \%$ reported off-task technology use in class. Over half of the students reported "often" or "always" using tech- 
nology for class-related purposes and this number increased as class size increased (53\% in small classes, $68 \%$ in medium-sized classes, and $72 \%$ in large classes). Self-reported off-task technology use was much lower than class-related technology use, with less than $30 \%$ of students reporting offtask technology use in class. Here, too, the number of students who "often" or "always" used technology for off-task purposes increased as the class size increased (11\% in small classes, $19 \%$ in medium sized classes, and 29\% in large classes). This is not surprising, given that large class sizes are known for being less personal learning environments. In large classes, where instructors are likely to be physically farther from the majority of their students, it is more challenging for instructors to learn the names of all their students and it can be difficult for instructors to feel as though they are able to make a personal connection with their students. From the students' perspective, the sense of connectedness with their instructor is lower in large versus small classes (Burruss et al., 2009). As is the case in large crowds, large classes set the stage for deindividuation; that is, feeling anonymous in a large class can lead students to behave differently than if they felt they were identifiable and held accountable for their actions (Gilovich, Keltner, Chen, \& Nisbett, 2016). On the contrary, in small classes where instructors are in closer proximity to their students and more likely to know students by name, students might feel that the instructor is more aware of their actions and, therefore, they (the students) might be more concerned about what the instructor thinks of their actions.

Approximately $22 \%$ of students reported being "somewhat" or "very" distracted by the sound of students typing on their laptops or tablets in class. We think it is particularly interesting that the sound of typing was perceived as distracting to some students, yet it was used as a cue by others, signaling them that the instructor just shared an important information that needs to be recorded in notes.

Seeing class-related material on other screens was "somewhat" or "very" distracting to only $9 \%$ of students. It was the off-task technology use that was more problematic: almost half of all student sample (e.g. 49\%) reported that seeing material unrelated to the course was "somewhat" or "very" distracting and this was more prominent in large versus small classes (53\% versus $43 \%$, respectively). The fact that students found this type of distraction more troubling in large classes points to the possibility that the quantity of distractions matters. Our findings are consistent with other current research on distractions from other students' screens displaying Facebook (Gupta \& Irwin, 2016; Langan et al., 2016) and other highly distracting activity such as gaming and movie watching (Langan et al., 2016).

Given that our survey focused on perceptions about technology use in class, we cannot extrapolate from this finding that students' learning is, indeed, unaffected by the distractions posed by the computers of others. It is now well-established that laptop multitasking has negative implication for learning not only for students who use the technology, but also for the students who sit next to them (Fried, 2008; Sana et al., 2013). It is possible, therefore, that students are unware of the degree to which the screens with unrelated to course material disrupt their learning. However, it is also possible that it is the position of the screen (e.g. in direct view of instructor) rather than its mere presence in the classroom that matters - a number of open-ended comments written by students pointed out the negative effect of seeing unrelated to course material on the screens of students sitting towards the front of the class.

Students also pointed to the benefits of technology for note-taking, commenting that they can type their notes faster than they can hand-write them. This is a topic of discussion in the literature. Mueller and Oppenheimer (2014) have demonstrated that when students hand-write their notes, they engage in generative note-taking, whereas when they use a laptop, they are mainly transcribing and not condensing or making decisions about what is important to record. It is possible that students use their non-generative, typed notes to create selective study notes outside of class. If this is the case, then taking notes on a laptop would not present a disadvantage. Further research is needed in this area. 
In our study, students seemed aware of when they were off-task with technology; further, they were intentional about using technology in this manner, either to alleviate boredom or to take a mental break from concentrating on content. These findings are consistent with previous research that shows that students use technology in class to alleviate boredom and concentration fatigue (Gupta \& Irwin, 2016; Langan et al., 2016). Taken together, these findings suggest that poor self-regulation is a simplistic and insufficient explanation for students' technology-related behaviours in class and it is likely not the only, or even the main, contributor to off-task technology use. The work of Gaudreau and colleagues (2014) supports this conclusion as they found that the association between in class off-task laptop use and low grade point average held even after controlling for self-regulation and other potential confounders. A number of researchers have found that students' attitudes, motivation, level of engagement, self-efficacy, and instructor's teaching strategies are important contributors to technology use behaviours (Bolkan \& Griffin, 2017; Langan et al., 2016; Santos et al., 2018; Taneja et al., 2015; Zhang, 2015).

Our study provided the opportunity to compare students' and instructors' perceptions of technology. Although a higher proportion of instructors expressed negative views of technology use than did students, we found that, in both groups, class-related use of technology was not considered to be particularly problematic. By contrast, students and instructors were more likely to see off-task technology use as a problem, however their level of agreement differed significantly. This finding is consistent with previous research comparing students' and instructors' perceptions, with instructors expressing stronger views than students (Baker et al., 2012; Santos et al., 2018). This is perhaps not surprising since open computer screens create physical and symbolic barrier for communication between instructors and students and can make instructors feel alienated from their students - a topic that we discuss in another paper (Neiterman \& Zaza, 2019). And since instructors do not see what is on the screens of their students, they might assume that students use their technological devices for unrelated to class purposes. We believe that this assumption is what can explain why instructors saw the use of cellphones as more troubling than the use of laptops - latter are generally used for taking notes and following Power Point slides, whereas the former are more likely to be used for texting and other unrelated to class activities. While this survey focused on the perception that technology can impact students' learning, it is also possible that technology has an impact on instructors - a promising area for future research.

Another key difference between students' and instructors' views was in who they held responsible for minimizing technology-related distractions in class. We found that instructors were much more likely than students to feel it is the teacher's responsibility to regulate technology use in class. Elsewhere we provide a more nuanced analysis of these differences (Neiterman \& Zaza, 2019), but here we would like to emphasize that one-third of instructors and students were undecided about whether or not instructors should do anything to minimize technology-related distractions in class. This uncertainty signifies to us that both groups need more information on this topic in order to form an opinion.

Our findings raise questions about what, if anything, should be done about students' self-initiated technology-use in class. Common strategies suggested in the literature include educating students about the impacts of technology use in class (Sana et al., 2013), establishing technology free zones (Aguilar-Roca et al., 2012) and engaging students, including providing more interactive options for note-taking and increasing technology use for class-related purposes (Bolkan \& Griffin, 2017; Grinols \& Rajesh, 2014). Future studies will hopefully provide evidenced-based knowledge on this topic. Given that small and large classes offer different opportunities for engagement, the effectiveness of strategies aimed to minimizing technology-related distractions should be tested and compared in all class sizes.

One clear message in our study was that given by students who felt strongly that they are adult learners, and as such, should be the ones in charge of their own technology-related behaviours in class. Students in Langan and colleagues' (2016) study expressed this sentiment as well; they felt that they should be allowed to do what they want as long as it does not have a negative impact on other stu- 
dents (Langan et al., 2016). It is advisable to consider how we, as educators, can engage students in changing the social and cultural norms of technology use in class. Education about the negative impact of technology use not only on students, but also on those around them, seems to us to be the first step in this direction. Figure 3 illustrates these findings.
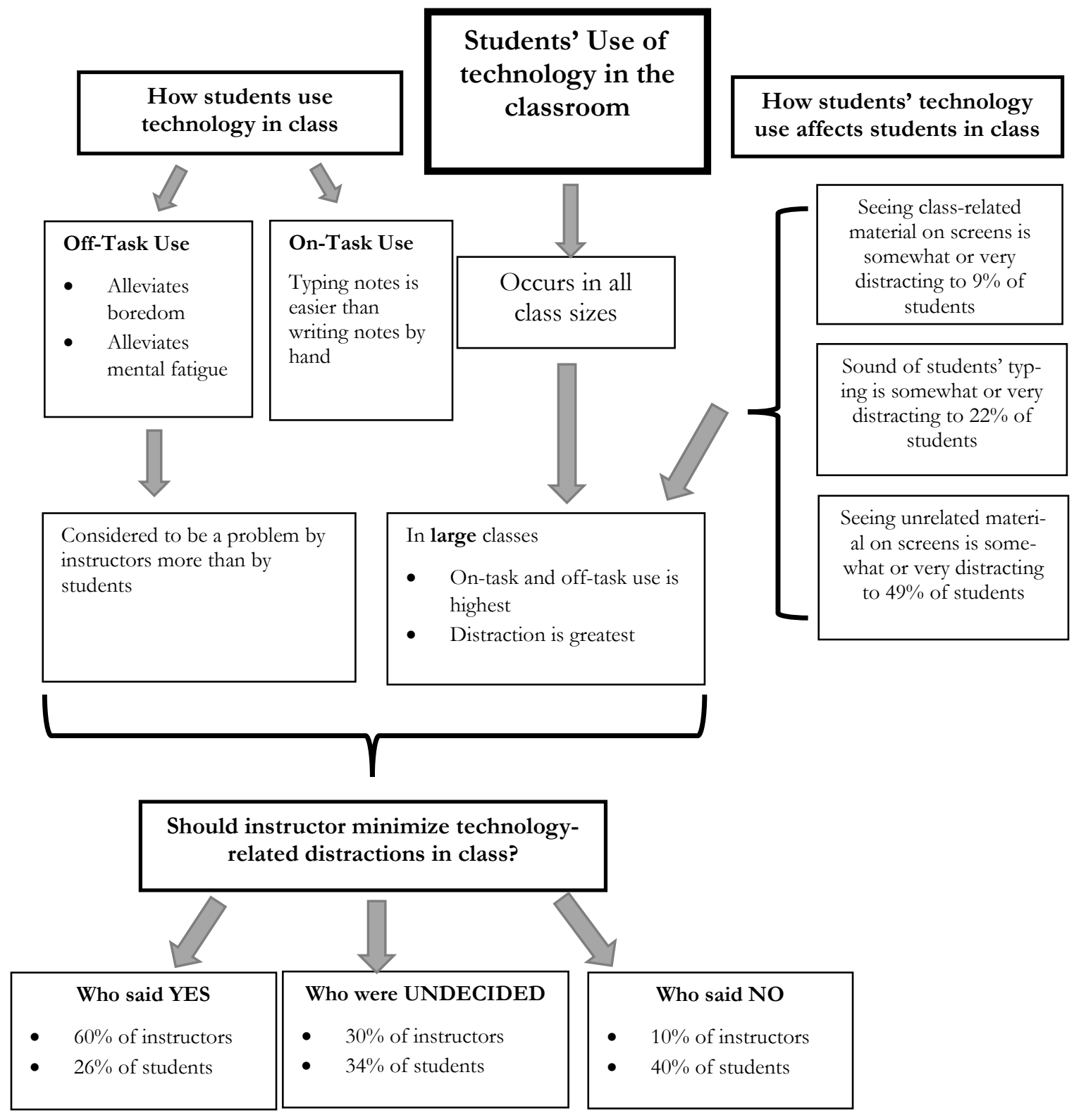

Figure 3. Summary of Findings

This exploratory study has several limitations. Our study was limited by low response rate among students $(21 \%)$. One possible reason for this may be that sending out recruitment email, we were not able to separate students who, at the time of the study, were on campus from students who were on their cooperative (co-op) education term. Many students are disconnected from campus life during the co-op term; they do not check their university-based emails and might be less inclined to take part in the study that examines classroom-related interactions. Excluding co-op students from our population, our response rate would have been $44 \%$, but we have no way of knowing if co-op stu- 
dents were less likely to take part in the study than on-campus students. In addition, although we addressed face validity by pilot-testing our survey questions, the survey was not formally tested for validity or reliability. Further, we chose to limit our survey to students and instructors in one Faculty; as such, further research in needed to examine the generalizability of our findings regarding class size. However, given that our findings concerning our secondary questions are consistent with other research on technology use and students' and instructors' perspectives, there is good reason to think that our results are generalizable. We recognize that comparing responses from a large number of students with responses from a small number of instructors is problematic; however, this study is meant to be an initial exploration of our research questions.

We did not ask respondents to provide their age; however, year of study might give an approximation of students' age. Although students were all taking courses in the Faculty of Applied Health Sciences, survey questions were not restricted to Applied Health Sciences courses. Therefore it is possible that subject matter differences affected students' responses. It is also possible that findings might differ according to the term of study. Because we conducted our survey only in the Fall term, we cannot comment on the generalizability of results to other terms.

In addition, our study was limited because we did not make distinctions between the type, frequency, and duration of off-task technology use even though these have been shown to be important factors that shape students' perceptions about others' use of technology in class (Langan et al., 2016; Santos et al., 2018).

\section{CONCLUSION}

Our study demonstrates that class size is an important factor to consider when examining the prevalence and perceptions of students' off-task technology use in class. This finding adds to current research that examines the factors that influence students' technology behaviours in the post-secondary classroom as, to our knowledge, none of the existing studies have examined class size as a potential factor. Our study also showed that, overall, class-related technology use was not considered particularly problematic by students or instructors. Although both groups agreed that off-task technology use in class was a problem, instructors expressed significantly stronger views than did students. While students and instructors disagreed about whether or not it is instructor's responsibility to remediate this problem, a substantial proportion of instructors and students was undecided. These findings support and extend current research that compares students' and instructors' views on this topic. Along with class size, both students' and instructors' perspectives on technology-use in class should be considered when developing measures to remediate this problem in the post-secondary classroom. These findings may be useful to educators who are developing measures to reduce technology-related distractions in the post-secondary classroom.

\section{ACKNOWLEDGEMENTS}

This research was supported by the University of Waterloo's Learning Innovation and Teaching Enhancement Grant.

\section{REFERENCES}

Aguilar-Roca, N. M., Williams, A. E., \& O’Dowd, D. K. (2012). The impact of laptop-free zones on student performance and attitudess in large lectures. Computers \& Education, 59(4), 1300-1308. https://doi.org/10.1016/i.compedu.2012.05.002

Alkahtani, M., Ahmad, A., Darmoul, S., Samman, S., Al-zabidi, A., \& Matraf, K. B. (2016). Multitasking trends and impact on education: A literature review. International Journal of Educational and Pedagogical Sciences, 10(3), 1006-1012. World Academy of Science, Engineering and Technology. Retrieved from https://waset.org/publications/10004600/multitasking-trends-and-impact-on-education-a-literaturereview 
Awwad, F., Ayesh, A., \& Awwad, S. (2013). Are laptops distracting educational tools in classrooms. Procedia Social and Behavioural Sciences, 103, 154-160. https://doi.org/10.1016/j.sbspro.2013.10.320

Baker, W. M., Lusk, E. J., \& Neuhauser, K. L. (2012). On the use of cell phones and other electronic devices in the classroom: Evidence from a survey of faculty and students. Journal of Education for Business, 87(5), 275289. https://doi.org/10.1080/08832323.2011.622814

Beland, L. P., \& Murphy, R. (2016). Ill Communication: Technology, distraction \& student performance. Labour Economics, 41, 61-76. https://doi.org/10.1016/i.labeco.2016.04.004

Bolkan, S., \& Griffin, D. J. (2017). Students' use of cell phones in class for off-task behaviors: The indirect impact of instructors' teaching behaviors through boredom and students' attitudes. Communication Education, 66(3), 313-329. https://doi.org/10.1080/03634523.2016.1241888

Braun, V., \& Clarke, V. (2006). Using thematic analysis in psychology. Qualitative Research in Psychology, 3(2), $77-$ 101. https://doi.org/10.1191/1478088706qp063oa

Burruss, N. M., Billings, D. M., Brownrigg, V., Skiba, D. J., \& Connors, H. R. (2009). Class size as related to the use of technology, educational practices, and outcomes in web-based nursing courses. Journal of Professional Nursing, 25(1), 33-41. https://doi.org/10.1016/i.profnurs.2008.06.002

Carter, S. P., Greenberg, K., \& Walker, M. (2017). The impact of computer usage on academic performance: Evidence from a randomized trial at the United States Military Academy. Economics of Education Review, 56, 118-132. https://doi.org/10.1016/j.econedurev.2016.12.005

Fried, C. B. (2008). In-class laptop use and its effects on student learning. Computers \& Education, 50(3), $906-914$. https://doi.org/10.1016/i.compedu.2006.09.006

Gaudreau, P., Miranda, D., \& Gareau, A. (2014). Canadian university students in wireless classrooms: What do they do on their laptops and does it really matter? Computers \& Education, 70, 245-255. https://doi.org/10.1016/j.compedu.2013.08.019

Gilovich, T. C., Keltner, D., Chen, S., \& Nisbett, R. E. (2016). Social psychology (4th edition). New York, NY: W. W. Norton \& Company, Inc.

Grinols, A., \& Rajesh, R. (2014). Multitasking with smartphones in the college classroom. Business and Professional Communication Quarterly, 77(1), 89-95. https://doi.org/10.1177/2329490613515300

Gupta, N., \& Irwin, J. D. (2016). In-class distractions: The role of Facebook and the primary learning task. Computers in Human Behavior, 55(Part B), 1165-1178. https://doi.org/10.1016/j.chb.2014.10.022

Junco, R., \& Cotton, S. R. (2012). No A 4 U: The relationship between multitasking and academic performance. Computers \& Education, 59(2), 505-514. https://doi.org/10.1016/j.compedu.2011.12.023

Langan, D., Schott, N., Wykes, T., Szeto, J., Kolpin, S., Lopez, C., \& Smith, N. (2016). Students' use of personal technologies in the university classroom: Analysing the perceptions of the digital generation. Technology, Pedagogy and Education, 25(1), 101-117. https://doi.org/10.1080/1475939X.2015.1120684

Ledbetter, A. M., \& Finn, A. N. (2016). Why do students use mobile technology for social purposes during class? Modeling teacher credibility, learner empowerment, and online communication attitude as predictors. Communication Education, 65(1), 1-23. https://doi.org/10.1080/03634523.2015.1064145

Lee, J., Lin, L., \& Robertson, T. (2012). The impact of media multitasking on learning. Learning, Media and Technology, 37(1), 94-104. https://doi.org/10.1080/17439884.2010.537664

Mboga, J., Mboga, M., \& Nyaanga, S. (2016). Distractions in learning institutions: An explorative case analysis of mobile device usage in Kenyan academia. International Journal of Education and Research, 4(3), 115-125. Retrieved from https://ijern.com/journal/2016/March-2016/09.pdf

Mueller, P. A., \& Oppenheimer, D. M. (2014). The pen is mightier than the keyboard. Advantages of longhand over laptop note taking. Psychological Science, 25(6), 1159-1168. https://doi.org/10.1177/0956797614524581

Neiterman, E., \& Zaza, C. (2019). A mixed blessing? Students' and instructors’ perspectives about off-task technology use in the academic classroom. The Canadian Journal for the Scholarship of Teaching and Learning, 10(1), 1-18. https://doi.org/10.5206/cjsotl-rcacea.2019.1.8002 
Ravizza, S. M., Hambrick, D. Z., \& Fenn, K. M. (2014). Non-academic internet use in the classroom is negatively related to classroom learning regardless of intellectual ability. Computers \& Education, 78, 109-114. https://doi.org/10.1016/i.compedu.2014.05.007

Rosen, L. D., Whaling, K., Carrier, L. M., Cheever, N. A., \& Rokkum, J. (2013). The media and technology usage and attitudes scale: An empirical investigation. Computers in Human Behavior, 29(6), 2501-2511. https://doi.org/10.1016/i.chb.2013.06.006

Sana, F., Weston, T., \& Cepeda, N. J. (2013). Laptop multitasking hinders classroom learning for both users and nearby peers. Computers \& Education, 62, 24-31. https://doi.org/10.1016/j.compedu.2012.10.003

Santos, I., \& Bocheco, O. (2016). Exploring BYOD usage in the classroom and policies. International Journal of Information and Communication Technology Education (IJICTE), 12(4), 51-61. https://doi.org/10.4018/IJICTE.2016100105

Santos, I., Bocheco, O., \& Habak, C. (2018). A survey of student and instructor perceptions of personal mobile technology usage and policies for the classroom. Education and Information Technologies, 23(2), 617-632. https://doi.org/10.1007/s10639-017-9625-y

Taneja, A., Fiore, V., \& Fischer, B. (2015). Cyber-slacking in the classroom: Potential for digital distraction in the new age. Computers \& Education, 82, 141-151. https://doi.org/10.1016/j.compedu.2014.11.009

Wood, E., Zivcakova, L., Gentile, P., Archer, K., De Pasquale, D., \& Nosko, A. (2012). Examining the impact of off-task multi-tasking with technology on real-time classroom learning. Computers \& Education, 58(1), 365-374. https://doi.org/10.1016/j.compedu.2011.08.029

Zhang, W. (2015). Learning variables, in-class laptop multitasking and academic performance: A path analysis. Computers \& Education, 81, 82-88. https://doi.org/10.1016/i.compedu.2014.09.012

\section{BIOGRAPHIES}

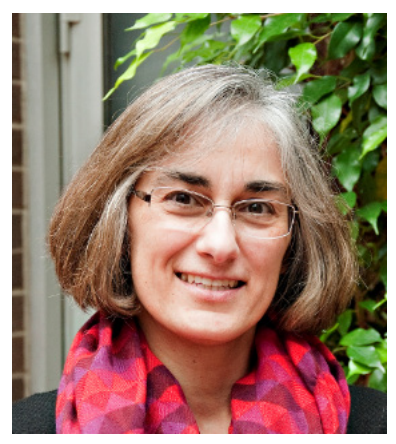

Christine Zaza is a Faculty Liaison with the Centre for Teaching Excellence, University of Waterloo where she supports faculty, teaching assistants, and staff in the design and implementation of instruction and blended learning. She holds a Ph.D. in Health Studies and Gerontology.

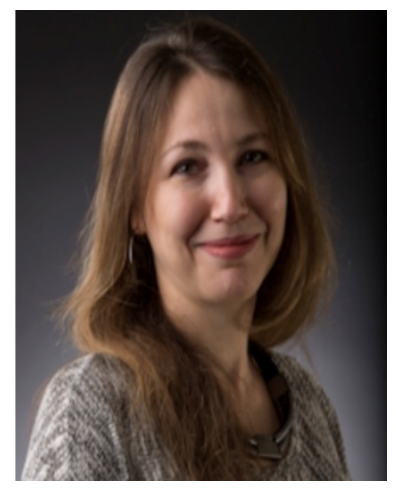

Elena Neiterman is a Teaching Fellow at the Faculty of Applied Health Sciences and a Continuing Lecturer at the School of Public Health and Health Systems of the University of Waterloo. She holds Ph.D. in Sociology and teaches courses to graduate and undergraduate students in health, sociology, and qualitative methods. 